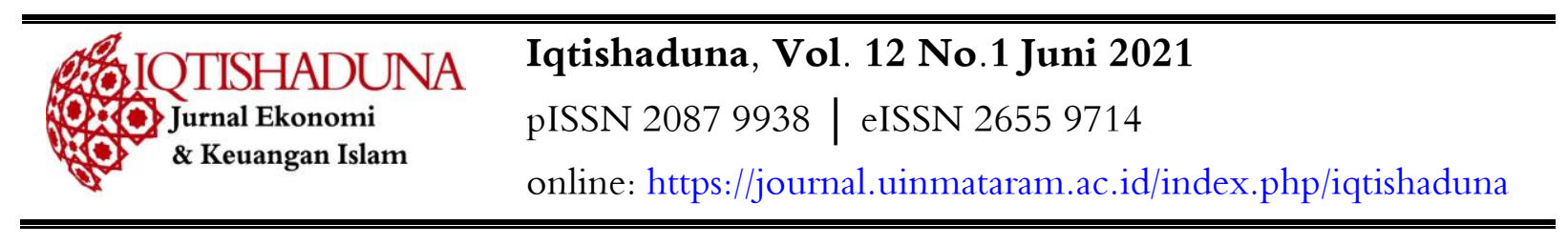

\title{
PENGARUH DOW JONES ISLAMIC MARKET INDEX (DJIMI) DI BEBERAPA NEGARA TERHADAP PERGERAKAN JAKARTA ISLAMIC INDEX (JII)
}

\author{
M Sugeng Prianto ${ }^{1}$, Darwanto ${ }^{2}$ \\ Universitas Diponegoro ${ }^{1,2}$ \\ $\underline{\text { Sugengprianto419@gmail.com }}{ }^{1}, \underline{\text { darwanto@live.undip.ac.id }}^{2}$
}

\begin{abstract}
Pergerakan Jakarta Islamic Index (JII) selalu diperhatikan oleh investor saham syariah dalam berinvestasi di pasar modal Indonesia. Hal ini dikarenakan JII merupakan Banchmark (tolak ukur) kinerja saham-saham syariah yang ada di Bursa Efek Indonesia. Kinerja JII dipengaruhi oleh berbagai faktor, baik faktor internal maupun eksternal. Dari internal JII dipengaruhi oleh variabel-variabel makroekonomi domestik, sedangkan dari eksternal kondisi ekonomi negara asing juga turut mempengaruhi pergerakan JII. Salah satu variabel eksternal adalah pergerakan indeks saham syariah Dow Jones Islamic Market (DJIM). Penelitian ini menggunakan 5 variabel indeks DJIMI yaitu Dow Jones Islamic Market Index United States (IMUS), Dow Jones Islamic Market Index Europe (DJIEU), Dow Jones Islamic Market Index Japan (DJIJP), Dow Jones Islamic Market Index Malaysia (DJIMY) dan Dow Jones Islamic Market Index China/Hongkong (DJICHK). Metode yang digunakan adalah Vector Error Correction Model (VECM). Hasil penelitian menunjukkan bahwa semua variabel independen tidak berpengaruh secara signifikan terhadap JII pada jangka pendek. Sedangkan pada jangka panjang, IMUS dan DJICHK mempengaruhi JII secara signifikan negatif sedangkan DJIJP dan DJIMY memiliki pengaruh signifikan positif terhadap JII. Sementara DJIEU tidak memberikan dampak yang signifikan terhadap JII baik dalam jangka pendek maupun jangka panjang.
\end{abstract}

Keywords : Jakarta Islamic Index (JII), Dow Jones Islamic Market Index (DJIMI), Vector Error Correction Model (VECM)

\section{PENDAHULUAN}

Pasar modal syariah Indonesia terus mengalami perkembangan setiap tahunnya. Data yang dirilis oleh Bursa Efek Indonesia menunjukkan jumlah investor syariah di pasar modal Indonesia sampai Bulan September 2019 mencapai 61.130 investor, jumlah ini mengalami peningkatan dari 44.536 investor pada akhir Tahun 2018. Meskipun mengalami pertumbuhan, jumlah tersebut masih tergolong kecil dibandingkan jumlah investor BEI secara keseluruhan. Data Kustodian Sentral Efek Indonesia (KSEI) mencatat total investor di BEI berjumlah 1,6 juta 
investor. Itu berarti jumlah investor yang menanamkan modalnya secara syariah baru mencapai 5 persen dari seluruh investor yang ada di BEI.

Transaksi saham yang terjadi di BEI saat ini didominasi oleh saham-saham yang sesuai dengan prinsip-prinsip syariah. Sebanyak 80 persen dari jumlah saham yang diperjualbelikan merupakan saham-saham emiten yang tercatat sebagai anggota Indeks Saham Syariah Indonesia (ISSI). Data Bulan Juli 2019 menyebutkan terdapat 635 saham yang terdaftar di Bursa Efek Indonesia. Dari jumlah tersebut 405 saham adalah saham syariah dengan kapitalisasi pasar mencapai Rp3.711,2 triliun, atau 51,2\% dari total kapitalisasi pasar modal Indonesia sebesar Rp7.248,4 triliun.

Indeks Harga Saham Gabungan (IHSG) pada Tahun 2019 berada di kisaran 5.900 sampai 6.400. Sejalan dengan hal tersebut, nilai kapitalisasi pasar bursa mencapai Rp7.243,045 triliun. Data Kustodian Sentral Efek Indonesia (KSEI) menunjukkan sampai Tanggal 9 Agustus 2019 dana yang berasal dari investor asing mencapai Rp1.907 triliun. Jumlah ini setara dengan 51,46 persen dari total ekuitas. Sedangkan jumlah dana dari investor domestik berjumlah Rp1.799 triliun, setara dengan 48,54 persen dari total ekuitas. Walaupun turun dibandingkan posisi akhir tahun 2018, porsi kepemilikan asing masih dominan atas kepemilikan saham di Bursa Efek Indonesia. Pada 28 Desember 2018, dana investasi yang dimiliki asing mencapai 52,17 persen ekuitas setara dengan Rp1.857 triliun. Sedangkan investor dalam negeri menguasai 47,83 persen dari total ekuitas setara Rp1.703 triliun. Kondisi pasar yang didominasi oleh investor asing memberikan risiko keuntungan dan kerugian terhadap bursa saham. Salah satu keuntungannya adalah jumlah dana yang ada di bursa saham bertambah besar. Sedangkan kerugiannya adalah apabila jumlah dana asing terlalu besar, maka pasar modal akan mengalami kejatuhan ketika para investor asing tersebut memutuskan untuk menarik dananya ke luar dari Indonesia secara bersama-sama.

JII merupakan indeks saham syariah utama yang ada di pasar modal Indonesia. Hal ini dikarenakan JII berisi saham-saham syariah dengan kapitalisasi pasar terbesar dan tingkat likuiditas tertinggi di Bursa Efek Indonesia. Sejak pertama kali didirikan pada tahun $2000 \mathrm{JII}$ terus mengalami pertumbuhan yang positif. Tujuan didirikannya JII adalah sebagai banchmark (tolak ukur) performa saham-saham syariah yang ada di BEI sekaligus berfungsi sebagai pemandu investor yang ingin berinvestasi di saham-saham syariah (Soemitro, 2014). Pada awal pendiriannya JII menggunakan Tahun dasar 1995 dengan nilai indeks sebesar 100. Dalam perjalanannya ada banyak faktor yang mempengaruhi nilai JII, yaitu dari faktor internal berupa variabel makro ekonomi domestik dan faktor eksternal berupa dinamika ekonomi di negara 
Prianto \& Darwanto. DJIMI \& JII

asing. Salah satu faktor ekternal yang berpengaruh terhadap fluktuasi nilai JII adalah pergerakan nilai indeks saham syariah yang ada di negara lain (Beik, 2014).

Dow Jones Islamic Market Index (DJIMI) merupakan indeks saham syariah terkemuka yang ada di dunia. Indeks ini kerap dijadikan acuan oleh para investor dunia yang ingin menanamkan dananya di saham-saham syariah. Dow Jones Islamic Market Index (DJIMI) tersebar di 34 negara meliputi saham-saham dari 18 sektor pasar, 51 kelompok industri, 10 sektor ekonomi, dan 89 subkelompok industri (Huda \& Nasution, 2008). Pasar modal beberapa negara yang memiliki indeks Dow Jones Islamic Market Index (DJIMI) adalah Amerika Serikat Dow Jones Islamic Market Index United States (IMUS), Eropa Dow Jones Islamic Market Index Europe (DJIEU), Jepang Dow Jones Islamic Market Index Japan (DJIJP), Malaysia Dow Jones Islamic Market Index Malaysia (DJIMY), dan China/Hongkong Dow Jones Islamic Market Index China/Hongkong (DJICHK). Saham-saham syariah dari negara-negara tersebut merupakan saham dengan harga yang cukup tinggi dibandingkan dengan saham-saham syariah di negara lainnya.

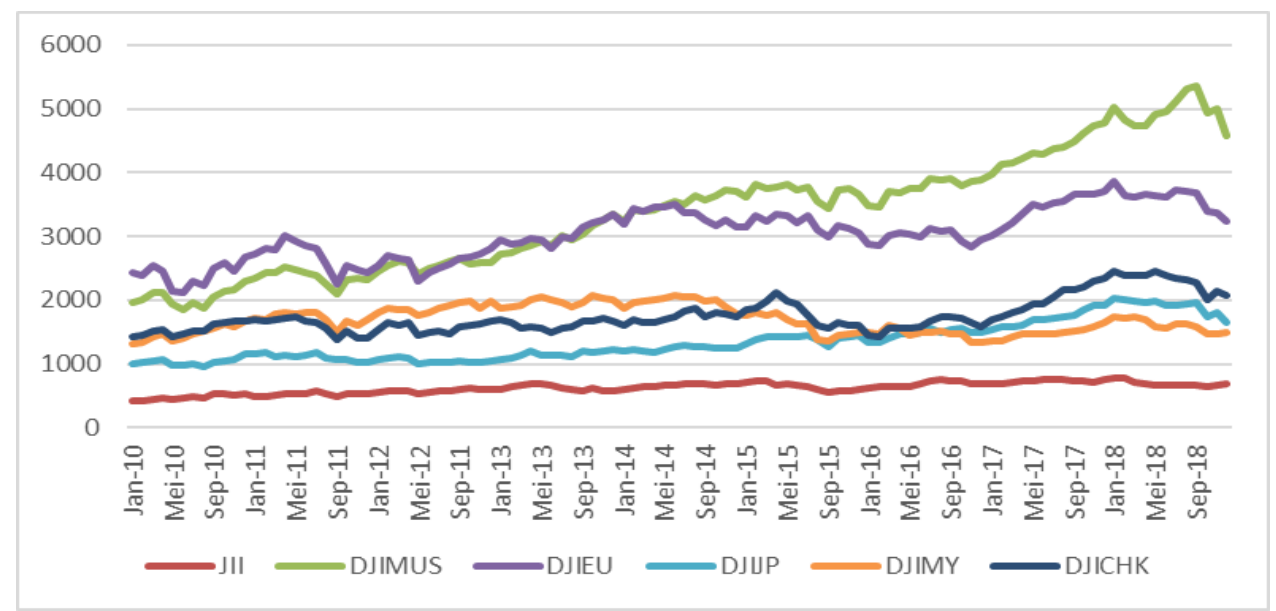

Gambar 1. Indeks Harga Saham Syariah Beberapa Negara

Sumber: www.bloomberg.com, diolah

Gambar 1 menampilkan fluktuasi nilai indeks saham syariah di beberapa negara terhadap Jakarta Islamic Index. Pada akhir periode tahun 2018 indeks harga saham syariah yang memiliki nilai tertinggi adalah Dow Jones Islamic Market Index United States (IMUS), diikuti oleh Dow Jones Islamic Market Index Europe (DJIEU), Dow Jones Islamic Market Index China/Hongkong (DJICHK) Dow Jones Islamic Market Index Malaysia (DJIMY), Dow Jones Islamic Market Index Japan (DJIJP) dan Jakarta Islamic Index (JII). Gambar tersebut juga menunjukkan bahwa pada akhir Tahun 2017 sampai awal Tahun 2018 semua Indeks saham syariah mengalami kenaikan. Hal ini dikarenakan kondisi ekonomi global pada periode tersebut tengah berada pada kondisi yang baik sehingga 
investor percaya untuk menanamkan modalnya di instrumen investasi beresiko salah satunya adalah saham.

Berbagai penelitian mengenai pengungkapan pengaruh indeks harga saham syariah di negera lain terhadap Jakarta Islamic Index (JII) menunjukkan hasil yang beraneka ragam. Penelitian yang dilakukan oleh Beik dan Fatmawati (2014) dengan meneliti IPI, CPI, JUB, Nilai Tukar, Suku Bunga, SBIS, DJIEU, IMUS, DJIJP, dan DJIMY terhadap Jakarta Islamic Index (JII) yang menggunakan data sekunder dengan metode VAR (Vector Autoregression), dan Vector Error Correction Model (VECM). Hasil penelitiannya menunjukkan JII dipangaruhi secara signifikan positif oleh DJIEU, DJIMY, dan terpengaruh secara negatif oleh DJIJP dan IMUS. Penelitian berikutnya dilakukan oleh Salihin dengan meneliti pengaruh Dow Jones Islamic Market Index (DJIMI), Dow Jones Islamic Market Index (DJIM) China, dan Indeks harga Sabam Gabungan (IHSG) terhadap Jakarta Islamic Index (JII). Hasil penelitian ini menunjukkan bahwa pada hasil Uji F, Dow Jones Islamic Market Index (DJIM), Dow Jones Islamic Market Index (DJIM) China dan Indeks Harga Saham Gabungan (IHSG) secara simultan berpengaruh terhadap Jakarta Islamic Indeks (JII).

Data dan fakta tersebut menunjukkan bahwa performa pasar modal syariah suatu negara sangat terpengaruh oleh dinamika pasar modal negara lain. Hal tersebut merupakan dampak dari semakin terintegrasikannya pasar-pasar modal di berbagai negara, yang mengakibatkan gejolak ekonomi di suatu negara secara signifikan dapat berpengaruh terhadap kondisi perekonomian negara lain. Penelitian ini dilakukan dengan tujuan menganalisa pengaruh pergerakan indeks harga saham syariah Dow Jones Islamic Market Index (DJIMI) di beberapa negara terhadap kinerja Jakarta Islamic Index (JII). Indeks Dow Jones Islamic Market Index (DJIMI) yang diteliti pengaruhnya adalah indeks DJIMI Amerika Serikat (IMUS), Eropa (DJIEU, Jepang (DJIJP), Malaysia (DJIMY), dan China/Hongkong (DJICHK).

\section{LITERATURE REVIEW}

Investasi keuangan syariah adalah investasi pada instrumen keuangan dengan berlandaskan pada prinsip-prinsip syariah (Mohamed Sherif, 2017). Perbedaan paling penting antara prinsip-prinsip investasi dalam Islam dan konvensional adalah selain mengecualikan sektor-sektor tertentu, dana Islam juga tidak boleh dikelola pada sektor yang berkaitan dengan pasar pendapatan tetap serta penerimaan atau pembayaran bunga (Hussein \& Omran, 2005). Abduh et al., (2011) menemukan bahwa sistem keuangan Islam memiliki keunggulan dibandingkan sistem keuangan konvensional, yaitu lebih stabil terhadap krisis keuangan karena sifat pembagian untungnya. Salah satu instrumen investasi keuangan syariah adalah saham syariah. 
Saham syariah merupakan sertifikat sebagai bukti penyertaan modal atas suatu unit usaha yang dikeluarkan oleh emiten yang pengelolaan dan kegiatan usahanya tidak bertentangan dengan nilai-nilai syariah (Soemitra, 2009). Kriteria saham syariah diantaranya adalah: perusahaan tidak berkaitan dengan perjudian atau perdangangan yang dilarang, bukan lembaga keuangan ribawi, tidak memproduksi, mendistribusikan serta memperdagangkan makanan dan minuman yang haram, tidak berkaitan dengan barang atau jasa yang dapat merusak moral dan membawa kemudharatan, serta tidak mempunyai hutang ribawi kepada lembaga keuangan konvensional yang lebih besar dibandingkan modal utamanya (Rodoni, 2009).

Indeks adalah indikator ataupun ukuran atas sesuatu. Di dalam dunia pasar modal, indeks atas saham maupun obligasi merupakan portofolio imaginer yang mengukur perubahan harga dari suatu pasar atau sebagian dari pasar tersebut. Bursa Efek Indonesia saat ini memiliki 24 indeks, beberapa diantaranya adalah Indeks Harga Saham Gabungan (IHSG), indeks LQ45, indeks KOMPAS100, Indeks Infobank15, indeks sektoral, dan Jakarta Islamic Indeks (JII). Indeks harga saham berfungsi sebagai indikator tingkat performa emiten yang terdaftar di indeks tersebut.

Indeks saham syariah adalah indeks yang dirancang untuk mematuhi ideologi Islam dengan pengelolaan dana yang diatur secara ketat untuk menghindari pembengkakan biaya dan cara lain untuk transfer yang tidak etis ke operator. (Ho, dkk: 2014). Listiyaningsih (2015) menyatakan bahwa pada dasarnya tidak ada perbedaan yang signifikan antara kinerja investasi saham syariah dan konvensional. Fakta tersebut membuat masyarakat dapat berkontribusi kepada negara dengan memberikan dana ke perusahaan yang membutuhkan tanpa khawatir dengan transaksi halal atau haram yang terjadi di dalamnya (Janitra, 2014). Hassan et. Al, (2005) dalam penelitiannya membuktikan bahwa kriteria syariah tidak selalu mengarah pada kinerja yang baik ataupun kinerja yang buruk. Oleh karena itu, investor tetap harus memahami kondisi pasar dalam menyusun strategi portofolio modal dalam konteks tingkat pengembangan dan area geografis serta faktor etika (Touiti \& Henchiri, 2017).

Jakarta Islamic Index (JII) merupakan indeks saham syariah yang berisi 30 emiten dengan nilai kapitalisasi pasar terbesar dan likuiditas tertinggi di Bursa Efek Indonesia. JII diluncurkan pada tanggal 3 Juli 2000 sebagai hasil kolaborasi antara PT Bursa Efek Indonesia (BEI) dengan PT Danareksa Investment Management dalam upaya membentuk instrumen untuk memandu investor yang ingin menanamkan modalnya berdasarkan prinsip-prinsip syariah (Beiq, 2014). JII menggunakan tahun dasar 1 Januari 1995 dengan nilai 100 pada saat awal pendiriannya.

Dow Jones Islamic Market Index (DJIMI) adalah anggota dari kelompok indeks Dow Jones Global Index (DJGI). Dalam melakukan seleksi saham syariah, S \& P Dow Jones Index bekerjasama 
dengan Ratings Intelligence Partners (RIP) untuk menyediakan screening terhadap saham-saham yang ada. Ratings Intelligence Partners adalah perusahaan konsultan yang berspesialisasi dalam solusi pasar investasi Islam dunia. Timnya terdiri dari para peneliti Islam terkualifikasi yang bekerja secara langsung dengan Dewan Pengawas Syariah (Shariah Supervisory Board).

Saham yang tergabung ke dalam Dow Jones Islamic Market Index (DJIMI) harus memenuhi kriteria yang ditentukan. Pertama dan yang utama, perusahaan tidak termasuk ke dalam kategori berikut: produk yang berkaitan dengan alkohol, produk terkait daging babi, jasa keuangan konvensional (berbasis bunga), hiburan, tembakau, dan senjata (Rahman, 2010). Farooq \& Reza, 2014) menambahkan, penyaringan ini didasarkan pada pedoman Islam bahwa ada hal-hal tertentu yang dilarang oleh Tuhan, sehingga transaksi yang menyangkut dengan kategori ini tidak sah. Kriteria saham DJIMI berikutnya adalah saham yang termasuk ke dalam DJIMI tidak boleh memiliki rasio utang melebihi 33\%, piutang terhadap total aset harus tetap di bawah $45 \%$ dan pendapatan bunga harus kurang dari 5\% atas total pendapatan. (Hakim \& Rashidian, 2002)

Dow Jones Islamic Market Index United States (IMUS) merupakan indeks saham syariah pertama yang diluncurkan di dunia. Indeks ini berbasis di New York Stock Exchange (NYSE), Amerika Serikat. Indeks ini menggunakan tahun dasar 1996. Pada saat dimulai, harga indeks IMUS hanya bernilai 1092,29. Saat ini, indeks IMUS sudah mengalami kenaikan hingga empat kali lipat.

Dow Jones Islamic Market Index Europe (DJIEU) merupakan salah satu Index saham syariah dengan nilai tertinggi di dunia. Menggunakan tahun dasar 1996, DJIEU memulai harga indeksnya dengan nilai 1.343,38. Setelah dua puluh tiga tahun, DJIEU kini sudah bernilai lebih dari tiga kali lipat senilai 3.230,79.

Dow Jones Islamic Market Index Japan (DJIJP) merupakan salah satu indeks saham syariah dalam Dow Jones Islamic Market Index family yang berbasis di Jepang. Menggunakan tahun dasar 1996, DJIJP memulai perjalanannya dengan harga 784,95. Saat ini, harga index ini sudah mengalami kenaikan lebih dari 150\% dibandingkan dengan saat pertama kali diluncurkan.

Dow Jones Islamic Market Index Malaysia (DJIMY) merupakan indeks saham syariah DJIMI Family yang kerap menjadi acuan bagi para investor dalam berinvestasi di asia terutama di bursa saham Malaysia. Pada saat peluncuran, DJIMY memulai harga indeks pada level 1.883,97. Kemudian harga indeks ini terus bergerak dinamis mengikuti pasar bursa dengan segala gejolak yang dialami oleh Malaysia dan Asia pada tahun-tahun berikutnya.

Dow Jones Islamic Market China/Hongkong (DJICHK) merupakan salah satu indeks saham anggota DJIMI family yang tergolong baru. DJICHK mengawali perjalanan sebagai indeks acuan 
Prianto \& Darwanto. DJIMI \& JII

saham syariah dengan menggunakan tahun dasar 2005. Pada saat pembukaan, nilai harga DJICHK berada pada level 1.000,00.

\section{METODOLOGI}

Penelitian ini memakai data sekunder berupa time series bulanan yang didapatkan dari website resmi www.bloomberg.com dengan memanfaatkan fasilitas Bloomberg Financial Laboratory di Fakultas Ekonomika dan Bisnis Universitas Diponegoro. Data-data tersebut adalah data harga Jakarta Islamic Index (JII) sebagai variabel terikat (dependen) sedangkan variabel independennya adalah Dow Jones Islamic Market Index United States (IMUS), Dow Jones Islamic Market Index Europe (DJIEU), Dow Jones Islamic Market Index Japan (DJIJP), Dow Jones Islamic Market Index Malaysia (DJIMY), dan Dow Jones Islamic Market Index China/Hongkong (DJICHK). Semua data dimulai dari periode Januari 2010 hingga Desember 2018.

Permasalahan yang terdapat pada penelitian ini akan dianalisis menggunakan metode Vector Autoregression (VAR) apabila analisis di tingkat level data yang digunakan telah stasioner. Tetapi jika data yang dianalisis belum stasioner pada tingkat level, maka pengujian dilanjutkan pada tingkat first difference. Kemudian metode VAR dikombinasikan dengan metode Vector Error Correction Model (VECM). Seluruh data yang digunakan pada penelitian ini diubah ke dalam bentuk logaritma natural (ln).

VAR adalah metode yang memberikan gambaran hubungan yang "saling menyebabkan" (kausalistis) antarvariabel dalam sistem, dengan memberikan tambahan berupa intercept. Metode penelitian yang dikembangkan oleh Christopher Sims pada tahun 1980 ini merupakan metode yaang disebut sebagai model yang ateoritis (tidak berdasar teori) karena mengasumsikan bahwa semua variabel dalam model bersifat endogen (ditentukan di dalam model). Firdaus (2011)menjelaskan bahwa apabila sebelumnya univariate autoregression adalah sebuah single equation (persamaan tunggal) dengan single-variable linear model (model linier variabel tunggal), di mana nilai lag-nya sendiri yang menjelaskan nilai sekarang dari masing-masing variabel, maka VAR merupakan sebuah n-persamaan dengan n-variabel, di mana nilai lag-nya sendiri, serta nilai saat ini dan masa lampaunya (current and past values) yang menjelasakan masing-masing variabel.

Uji Vector Autoregression (VAR) dilakukan apabila data tidak terkointegrasi. Jika data yang digunakan terkointegrasi dan stasioner pada tingkat first difference maka model VAR dikombinasikan dengan metode Vector Error Correction Model (VECM). VECM digunakan untuk menghitung hubungan antar variabel pada jangka panjang dan jangka pendek. Hasil VECM dikatakan mempunyai pengaruh jika nilai t-statistik lebih besar dibandingkan nilai t-tabel, 
sehingga hasil tersebut dapat disimpulkan bahwa terdapat hubungan jangka panjang atau jangka pendek antar-variabel.

\section{HASIL DAN PEMBAHASAN}

Tahap pertama adalah uji akar unit untuk mengetahui stasioneritas data. Uji stasioneritas data adalah tahapan yang perlu dilakukan dalam menganalisis data time series. Di dalam penelitian ini metode pengujian yang digunakan adalah uji ADF (Augmented Dickey-Fuller) pada taraf nyata lima persen. Apabila nilai t-ADF lebih besar dibandingna dengan nilai kritis MacKinnon, maka itu berarti data yang digunakan tidak mengandung akar unit (stasioner).

Tabel 1. Hasil Uji Akar Unit Pada Level

\begin{tabular}{|c|c|c|c|c|c|}
\hline \multirow[t]{2}{*}{ Variabel } & \multirow{2}{*}{ Nilai ADF } & \multicolumn{3}{|c|}{ Nilai Kritis McKinnon } & \multirow{2}{*}{ Keterangan } \\
\hline & & $1 \%$ & $5 \%$ & $10 \%$ & \\
\hline JII & -2.297666 & -3.492523 & -2.888669 & -2.581313 & Tidak stasioner \\
\hline IMUS & -0.884356 & -3.492523 & -2.888669 & -2.581313 & Tidak stasioner \\
\hline DJIEU & -1.857125 & -3.492523 & -2.888669 & -2.581313 & Tidak stasioner \\
\hline DJIJP & -0.909683 & -3.492523 & -2.888669 & -2.581313 & Tidak stasioner \\
\hline DJIMY & -1.996378 & -3.492523 & -2.888669 & -2.581313 & Tidak stasionet \\
\hline DJICHK & -1.527310 & -3.492523 & -2.888669 & -2.581313 & Tidak stasioner \\
\hline
\end{tabular}

Hasil uji akar unit di tingkat level menunjukkan bahwa keenam variabel tidak ada yang stasioner pada taraf nyata lima persen. Sebagaimana dapat diamati pada tabel 1 bahwa semua nilai mutlak t-ADF lebih kecil dari MacKinnon Critical Value-nya pada taraf nyata 5\%. Data yang tidak stasioner pada penelitian bisa menghasilkan regresi palsu (spurious regressin), sehingga pengujian stasionaritas data berlanjut di tingkat first difference.

Tabel 2. Hasil Uji Akar Unit Pada First Difference

\begin{tabular}{lcrrrl}
\hline \multirow{2}{*}{ Variabel } & Nilai ADF & \multicolumn{3}{c}{ Nilai Kritis McKinnon } & Keterangan \\
\cline { 3 - 4 } & & $1 \%$ & $5 \%$ & $10 \%$ & \\
JII & -10.14571 & -3.493129 & -2.888932 & -2.581453 & Stasioner \\
IMUS & -10.53533 & -3.493129 & -2.888932 & -2.581453 & Stasioner \\
DJIEU & -11.28594 & -3.493129 & -2.888932 & -2.581453 & Stasioner \\
DJIJP & -10.87815 & -3.493129 & -2.888932 & -2.581453 & Stasioner \\
DJIMY & -10.26997 & -3.493129 & -2.888932 & -2.581453 & Stasioner \\
DJICHK & -9.947618 & -3.493129 & -2.888932 & -2.581453 & Stasioner \\
\hline
\end{tabular}

Hasil uji stasioneritas data di tingkat first difference menunjukkan bahwa seluruh variabel telah stasioner pada taraf nyata lima persen. Di mana nilai mutlak t-ADF lebih besar dibandingkan nilai mutlak MacKinnon Critical Value-nya pada taraf nyata 5\%.

Tahap kedua adalah penentuan lag optimal. Tabel 3 menunjukkan hasil pengujian lag optimal. Berdasarkan perhitungan nilai Akaike Information Criterion (AIC), lag optimal dalam penelitian ini berada pada lag 1. 
Tabel 3 . Hasil Uji Akar Uji Lag Optimal

\begin{tabular}{ccccccc}
\hline Lag & LogL & LR & FPE & AIC & SC & HQ \\
0 & -3820.368 & NA & $6.93 \mathrm{e}+25$ & 76.52735 & 76.68366 & 76.59061 \\
1 & -3196.367 & 1160.641 & $5.42 \mathrm{e}+20^{*}$ & $64.76734^{*}$ & $65.86151^{*}$ & $65.21017^{*}$ \\
2 & -3165.955 & 52.91701 & $6.10 \mathrm{e}+20$ & 64.87910 & 66.91113 & 65.70150 \\
\hline
\end{tabular}

Tahap ketiga adalah uji kointegrasi. Pengujian kointegrasi dapat dilakukan setelah semua variabel stasioner pada tingkat first difference. Uji kointegrasi dalam penelitian ini menggunakan uji Johansen cointegration test. Pengujian ini dilakukan untuk mengetahui jumlah kointegrasi yang terdapat pada model. Uji kointegrasi pada Tabel 4 menunjukkan bahwa nilai Trace statistic 0 (none) dan At most 1 memiliki nilai yang lebih besar dibandingkan dengan nilai pada Critical $V$ alue di taraf nyata 5\%. Hal itu berarti bahwa terdapat kointegrasi pada data tersebut. Hasil tersebut mengindikasikan bahwa terdapat hubungan jangka panjang dan jangka pendek antar variabel yang diuji.

\section{Tabel 4 . Hasil Uji Akar Uji Kointegrasi}

\begin{tabular}{|c|c|c|c|c|}
\hline $\begin{array}{l}\text { Hypothesized } \\
\text { No. of CE(s) }\end{array}$ & Eigenvalue & $\begin{array}{c}\text { Trace } \\
\text { Statistic }\end{array}$ & $\begin{array}{c}0.05 \\
\text { Critical Value }\end{array}$ & Prob.** \\
\hline None * & 0.482714 & 272.2669 & 95.75366 & 0.0000 \\
\hline At most $1 *$ & 0.452192 & 203.0553 & 69.81889 & 0.0000 \\
\hline At most $2 *$ & 0.364981 & 139.8631 & 47.85613 & 0.0000 \\
\hline At most $3 *$ & 0.324781 & 92.18250 & 29.79707 & 0.0000 \\
\hline At most $4 *$ & 0.248404 & 50.94713 & 15.49471 & 0.0000 \\
\hline At most $5 *$ & 0.180986 & 20.96371 & 3.841466 & 0.0000 \\
\hline
\end{tabular}

Uji kointegrasi yang telah dilakukan pada langkah sebelumnya menunjukkan bahwa terdapat kointegrasi dari masing-masing variabel. Oleh sebab itu metode yang digunakan adalah VECM. Estimasi VECM dilakukan untuk melihat adanya korelasi pada jangka pendek dan jangka panjang. Apabila nilai t-statistik lebih besar daripada nilai t-tabelnya, maka dapat dikatakan bahwa terdapat hubungan yang signifikan pada jangka panjang atau jangka pendek. Adapun nilai t-tabel yang diperoleh dari pengolahan model pada tabel $\mathrm{t} d=102$ untuk nilai kritis $5 \%$ adalah 1.65993.

Hasil uji estimasi VECM pada Tabel 5 menunjukkan terdapat koreksi kesalahan sebesar 0.007862 pada jangka pendek. Hal ini dapat diinterpretasikan untuk mencapai keseimbangan jangka panjang dibutuhkan koreksi kesalahan sebesar 0.007862\%. Nilai ini dilihat dari CointEq1 sebesar -0.007862 .

Hasil estimasi VECM menunjukkan bahwa semua variabel independen tidak ada yang memberikan pengaruh secara signifikan terhadap Jakarta Islamic Index (JII) pada jangka pendek. Hal ini disebabkan semua nilai t-Statistik setiap variabel lebih kecil dari nilai t-Tabelnya. Masing- 
masing nilai t-Statistic kelima variabel tersebut adalah $0.48401<1.65993$ untuk IMUS, $0.78266<1.65993$ untuk DJIEU, $0.32058<1.65993$ untuk DJIP, $0.27192<1.65993$ untuk DJIMY, dan $-0.25824<1.65993$ untuk DJICHK. Berdasarkan hasil tersebut dapat ditarik kesimpulan bahwa investor yang menanamkan modalnya di saham-saham syariah memiliki orientasi investasi jangka panjang dengan tujuan mendapatkan return di masa depan bukan untuk tujuan trading atau spekulasi.

Tabel 5. Hasil Estimasi VECM

\begin{tabular}{lcc}
\hline \multicolumn{3}{c}{ Jangka Panjang } \\
\hline \multicolumn{1}{c}{ Variabel } & Koefisien & t-Statistik \\
IMUS & -0.320279 & $*[3.60765]$ \\
DJIEU & -0.071972 & {$[0.84494]$} \\
DJIJP & 1.385298 & $*[-7.89171]$ \\
DJIMY & 0.530382 & $*[-5.11953]$ \\
DJICHK & -0.477236 & $*[4.41184]$ \\
\multicolumn{1}{l}{ CointEq1 -0.007862 } & Jangka Pendek & \\
\multicolumn{1}{l|}{ Variabel } & Koefisien & t-Statistik \\
IMUS & 0.018725 & {$[0.48401]$} \\
DJIEU & 0.024797 & {$[0.78266]$} \\
DJIJP & -0.026766 & {$[-0.32058]$} \\
DJIMY & 0.013303 & {$[0.27192]$} \\
DJICHK & -0.011907 & {$[-0.25824]$} \\
\hline
\end{tabular}

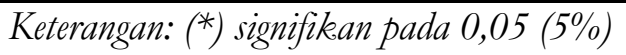

Persamaan jangka panjang dari hasil pengujian terdapat empat variabel independen yang memiliki pengaruh signifikan terhadap JII yaitu, IMUS, DJIJP, DJIMY dan DJICHK. Keempat variabel tersebut mempunyai nilai t-Statistic yang lebih besar dibandingkan dengan nilai t-Tabel yang masing-masing nilainya adalah 3.60765>1.65993 untuk variabel IMUS, -7.89171>1.65993 untuk variabel DJIJP, untuk variabel DJIMY -5.11953>1.65993, dan 4.41184>1.65993 untuk DJICHK. Namun demikian, variabel DJIEU tidak memberikan pengaruh yang signifikan kepada JII. Hal ini dikarenakan nilai t-Statistik dari variabel DJIEU (0.84494) lebih kecil dibandingkan nilai t-Tabel sebesar 1.65993.

Variabel IMUS memberikan pengaruh signifikan negatif terhadap JII. IMUS memiliki koefisien sebesar -0.320279. Besaran nilai koefisien ini mengindikasikan bahwa ketika terjadi peningkatan IMUS sebesar 1\% maka JII akan merespon dengan penurunan sebesar $0.320279 \%$. DJIJP memiliki pengaruh signifikan positif terhadap JII dengan nilai koefisien sebesar 1.385298 . Besaran nilai koefesien ini menunjukkan bahwa ketika DJIJP mengalami kenaikan 1\% akan diikuti peningkatan JII sebesar 1.385298\%. Variabel DJIMY memiliki pengaruh positif signifikan terhadap JII dengan nilai koefisien 0.530382. Hal ini berarti bahwa pada saat DJIMY mengalami 
kenaikan sebesar 1\% maka akan diikuti kenaikan JII sebesar $0.530382 \%$. Sedangkan variabel DJICHK memberikan pengaruh negatif siginifikan terhadap JII dengan koefisien sebesar 0.477236. Besaran nilai koefisien ini mengindikasikan bahwa ketika DJICHK mengalami kenaikan sebesar 1\% maka JII akan merespon dengan penurunan sebesar $0.477236 \%$.

Dow Jones Islamic Market Index United States (IMUS) dan Dow Jones Islamic Market Index China/Hongkong (DJCHK) pada jangka pendek tidak memberikan pengaruh yang signifikan terhadap Jakarta Islamic Index (JII) namun pada jangka panjang kedua variabel tersebut berpengaruh signifikan negatif terhadap JII. Hasil ini menunjukkan bahwa variabel Dow Jones Islamic Market Index United States (IMUS) dan Dow Jones Islamic Market Index China/Hongkong (DJICHK) pada periode 2010-2018 adalah kompetitor bagi Jakarta Islamic Index (JII). Hal ini dikarenakan investor cenderung mempertimbangkan kondisi ekonomi di ketiga negara tersebut. Ketika kondisi ekonomi Indonesia dianggap lebih baik dan dapat memberikan keuntungan investasi yang lebih besar dibandingkan Amerika Serikat atau China/Hongkong maka investor cenderung mengambil dananya dari Amerika Serikat dan China/Hongkong kemudian menginvestasikannya di saham-saham syariah yang ada di Indonesia. Begitu pula sebaliknya ketika pasar modal Amerika Serikat atau China/Hongkong dianggap bisa memberikan keuntungan yang lebih baik maka investor cenderung menarik dananya dari pasar saham syariah Indonesia dan menanamkan modalnya di pasar saham syariah Amerika Serikat atau China dan Hongkong. Hasil penelitian ini sejalan dengan penelitian yang dilakukan oleh Beik dan Fatmawati (2014) yang menyatakan Dow Jones Islamic Market Index United States (IMUS) memberikan pengaruh signifikan negatif kepada Jakarta Islamic Indeks (JII) dan penelitian yang dilakukan oleh Salihin (2018) yang menunjukkan bahwa pada hasil Uji F, Dow Jones Islamic Market Index (DJIM) China/Hongkong secara simultan berpengaruh terhadap Jakarta Islamic Indeks (JII).

Dow Jones Islamic Market Index Japan (DJIJP) dan Dow Jones Islamic Market Index Malaysia (DJIMY) pada jangka pendek tidak memberikan pengaruh yang signifikan kepada Jakarta Islamic Index (JII) tetapi pada jangka jangka panjang kedua variabel tersebut memberikan pengaruh yang signifikan dan positif. Hal ini membuktikan bahwa hubungan antara variabel Dow Jones Islamic Market Index Japan (DJIJP) dan Dow Jones Islamic Market Index Malaysia (DJIMY) terhadap Jakarta Islamic Index (JII) pada periode 2010-2018 adalah bukan kompetitor, karena pasar modal syariah ketiga negara tersebut tidak saling memperebutkan dana yang sama dari para investor. Hal ini terjadi karena fundamental ekonomi Indonesia, Jepang dan Malaysia relatif sama sehingga ketika kondisi ekonomi salah satu negara tersebut tengah berada pada kondisi baik maka dua negara lainnya juga sedang baik. Kondisi ini mendorong kepercayaan investor untuk menginvestasikan dananya di pasar modal baik di saham-saham syariah yang ada di Jepang, Malaysia maupun 
Indonesia sesuai dengan porsinya masing-masing. Begitu pula sebaliknya ketika ekonomi salah satu negara tersebut mengalami kelesuan, maka hal yang sama juga terjadi pada kedua negara lainnya yang berdampak pada penurunan jumlah investasi yang ditanamkan investor di pasar modal syariah ketiga negara tersebut. Hasil penelitian ini berbeda dengan penelitian yang dilakukan oleh Abidin (2007) yang menunjukkan bahwa pada jangka panjang Dow Jones Islamic Market Index Japan (DJIJP) memiliki pengaruh negatif signifikan terhadap Jakarta Islamic Index (JII). Namun untuk variabel Dow Jones Islamic Market Index Malaysia (DJIMY) sejalan dengan hasil penelitian yang dilakukan oleh Oktaviani (2017) di mana Dow Jones Islamic Market Index Malaysia (DJIMY) memberikan pengaruh positif signifikan terhadap Jakarta Islamic Index (JII).

Dow Jones Islamic Market Index Europe (DJIEU) tidak memberikan pengaruh yang signifikan baik dalam jangka pendek maupun jangka panjang terhadap Jakarta Islamic Index (JII). Hal ini menunjukkan bahwa hubungan antara Dow Jones Islamic Market Index Europe (DJIEU) dan Jakarta Islamic Index (JII) adalah netral. Kondisi ini terjadi karena investor yang menanamkan modalnya di saham-saham syariah yang terdapat di bursa saham Indonesia tidak mempertimbangkan kondisi pasar modal syariah yang ada di Eropa, begitu pula sebaliknya. Hal ini disebabkan jumlah investor yang memiliki portofolio saham Jakarta Islamic Index (JII) yang beririsan dengan saham-saham anggota Dow Jones Islamic Market Index Europe (DJIEU) relatif kecil sehingga ketika terjadi dinamika pasar di kedua negara tidak saling mempengaruhi secara signifikan. Hasil penelitian ini didukung oleh penelitian yang dilakukan oleh Oktaviani (2017) yang menyatakan bahwa Dow Jones Islamic Market Index Europe (DJIEU) tidak memberikan pengaruh yang signifikan terhadap Jakarta Islamic Index (JII).

Tahap berikutnya adalah Uji Impulse Respons Function (IRF). Uji IRF digunakan untuk mengetahui bagaimana reaksi suatu variabel ketika mendapat guncangan (shock) dari variabel lainnya. Analisis IRF berguna untuk menelusuri dampak suatu guncangan terhadap seluruh variabel sepanjang periode waktu tertentu. Gambar 2 berikut menunjukkan respon JII atas guncangan dari setiap variabel-variabel independen dalam penelitian ini.

Gambar 2 menunjukkan respon Jakarta Islamic Index (JII) terhadap guncangan dari variabel Dow Jones Islamic Market Index United States (IMUS) secara positif pada periode kedua sebesar 3,62\% dan menurun menjadi negatif pada periode ketiga sebesar 0,68\%. Kemudia kembali naik pada periode keempat serta kembali turun pada periode kelima. Lalu naik kembali pada periode keenam. Respon JII mulai mencapai keseimbangan pada periode kesepuluh sebesar $1,43 \%$. 

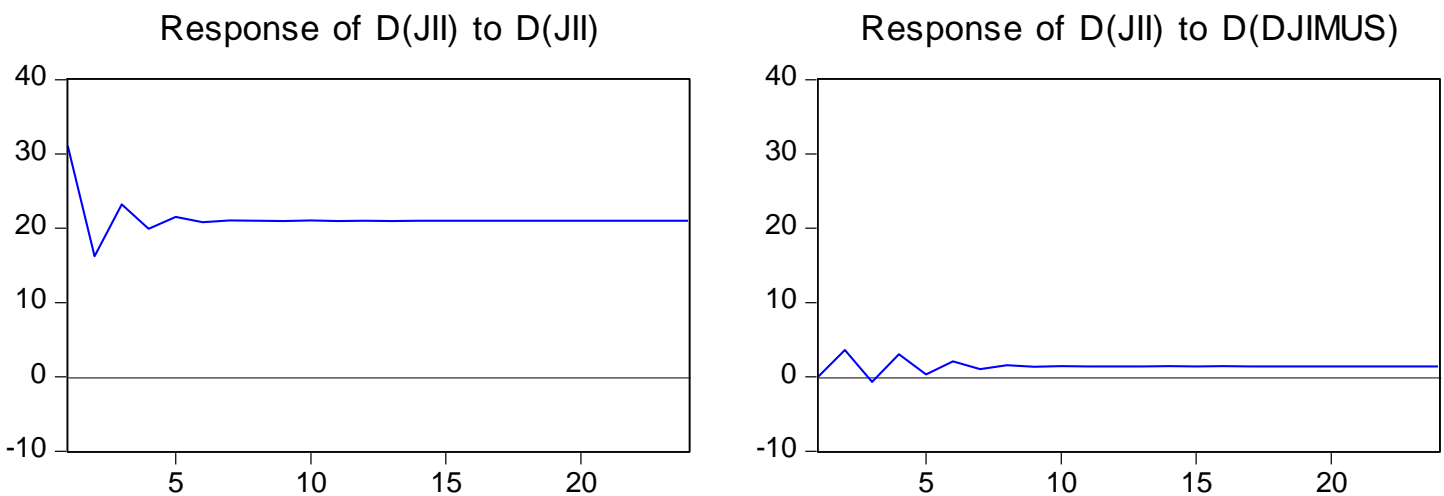

Response of $\mathrm{D}(\mathrm{JII})$ to $\mathrm{D}(\mathrm{DJIEU})$

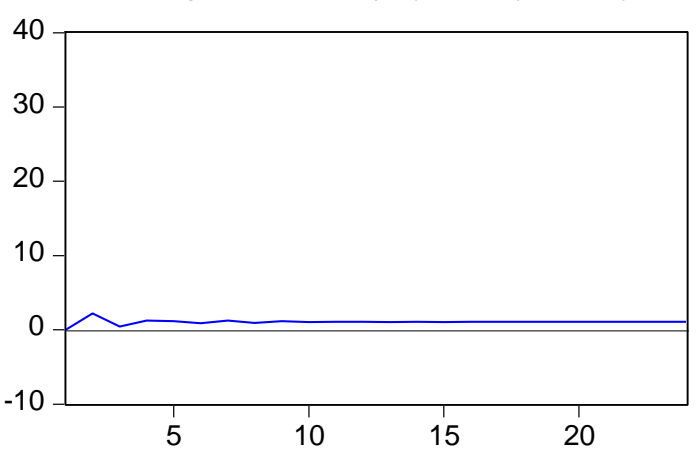

Response of $D(J I I)$ to $D(D J I J P)$

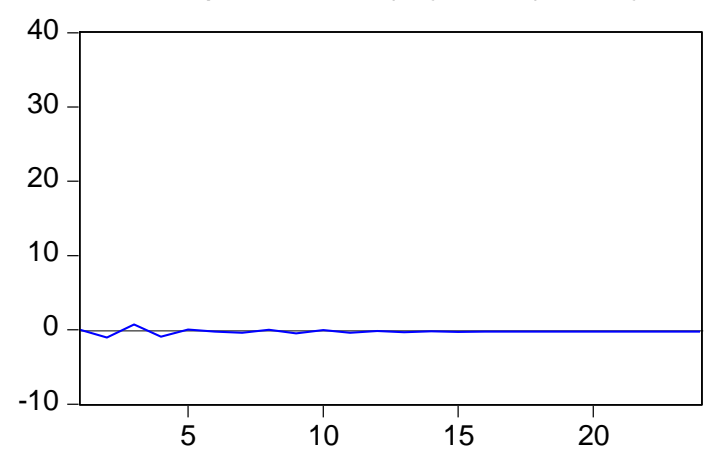

Response of $\mathrm{D}(\mathrm{JII})$ to $\mathrm{D}(\mathrm{DJIMY})$

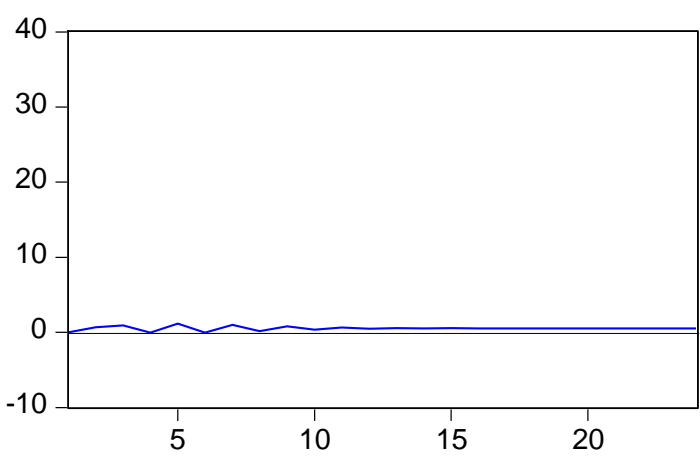

Response of $\mathrm{D}(\mathrm{JII})$ to $\mathrm{D}(\mathrm{DJICHK})$

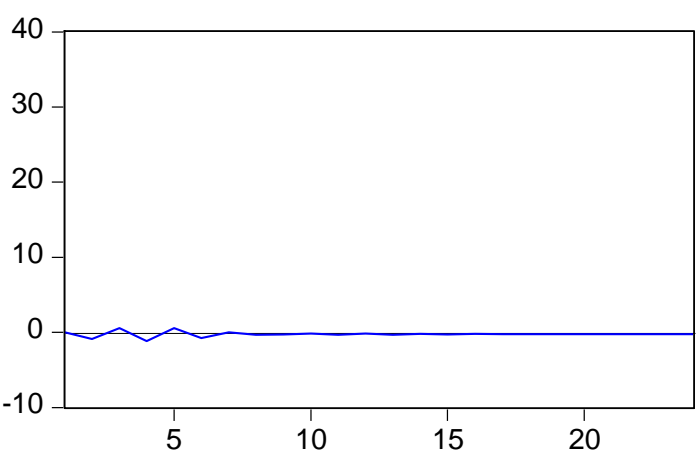

Gambar 2. Hasil Impulse Response Function

Respon Jakarta Islamic Index (JII) terhadap guncangan dari Dow Jones Islamic Market Index Europe (DJIEU) adalah respon positif pada periode kedua sebesar 2,22\%. Kemudian menurun pada periode ketiga sebesar $0,43 \%$ dan kembali naik pada periode ketiga sebesar 1,23\%. Penurunan kembali terjadi pada periode keempat dan kelima. Respon JII baru mencapai kestabilan pada periode kesepuluh sebesar 1.04\%.

Guncangan variabel Dow Jones Islamic Market Index Japan (DJIJP) direspon oleh Jakarta Islamic Index (JII) secara negatif pada periode kedua sebesar 1,04\% lalu naik menjadi 0,73\% pada periode ketiga. Kemudian kembali mengalami respon negatif sebesar 0,93\% pada periode keempat. Respon JII baru mencapai kestabilan pada periode ke-14 sebesar 0,20\%. 
Respon Jakarta Islamic Index (JII) terhadap guncangan Dow Jones Islamic Market Index Malaysia (DJIMY) mengalami respon positif pada periode kedua sebesar 0,69\%. Kemudian naik menjadi $0,90 \%$ pada periode ketiga. Akan tetapi pada periode keempat JII mengalami respon negatif sebesar $0,05 \%$. Lalu naik menjadi 1,15\% pada periode ke-5 dan kembali negatif pada periode ke-6 sebesar 0,04\%. Respon JII baru mengalami keseimbangan pada periode ke-13 sebesar $0,56 \%$.

Guncangan Dow Jones Islamic Market Index China/Hongkong (DJICHK) terhadap Jakarta Islamic Index (JII) direspon negatif pada periode ke-2 sebesar 0,88\%. Kemudian mengalami kenaikan pada periode ketiga sebesar 0,58\% dan kembali negatif sebesar 1,13\% pada periode keempat. Lalu pada periode ke-5 JII merespon dengan positif sebesar 0,55\% akan tetapi kembali negatif pada periode ke-6 sebesar 0,75\%. Respon JII baru mencapai kestabilan pada periode ke15 sebesar $0,26 \%$.

Tahap terakhir adalah Uji Forecast Variance Decomposition Error (FEVD). Tabel 6 menunjukkan bahwa pada periode ke-1, fluktuasi Jakarta Islamic Index (JII) disebabkan oleh guncangan Jakarta Islamic Index (JII) itu sendiri sebsar 100\%. Namun, sejak periode ke-2 hingga ke-24 besarnya persentase guncangan JII terus berfluktuasi karena guncangan dari variabel lain mulai mempengaruhi variabel Jakarta Islamic Index (JII).

\section{Tabel 6. Hasil Uji Forecast Variance Decomposition Error Variance Decomposition of D(JII)}

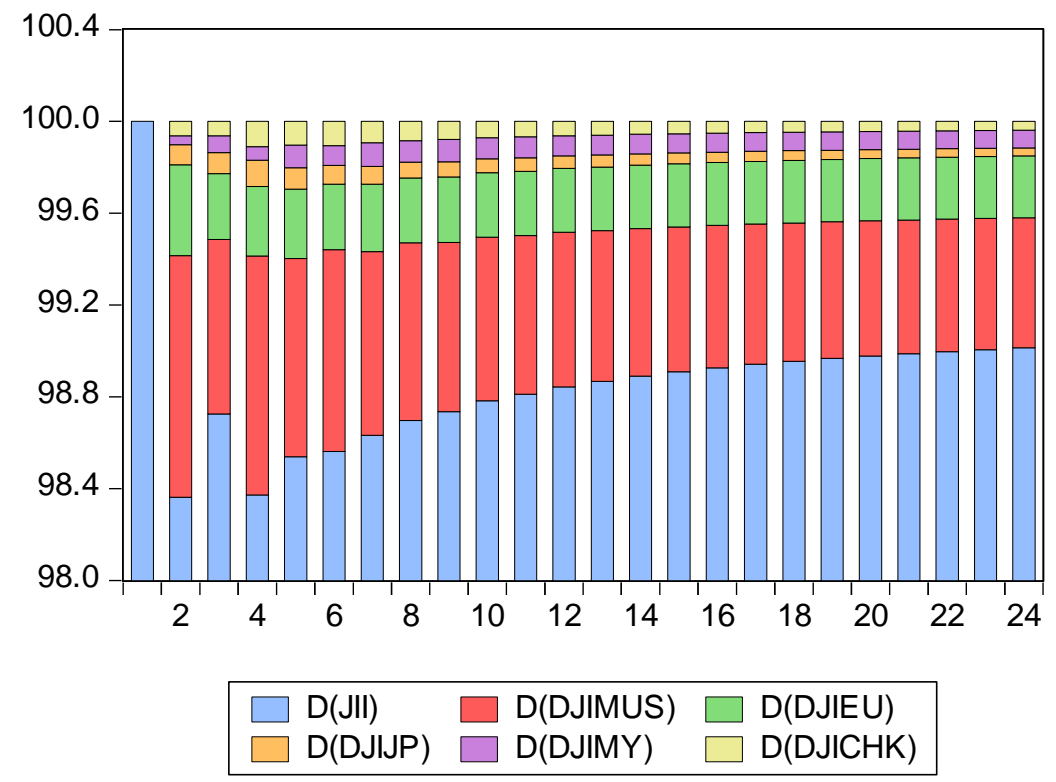

Pada periode ke-2 guncangan Jakarta Islamic Index (JII) yang disebabkan oleh variabel Jakarta Islamic Index (JII) itu sendiri terjadi sebesar 98,36\%. Jumlah persentase tersebut masih 
Prianto \& Darwanto. DJIMI \& JII

mendominasi terhadap guncangan Jakarta Islamic Index (JII). Sedangkan variabel lain yang mulai mempengaruhi guncangan JII adalah Dow Jones Islamic Market Index United States (IMUS) sebesar 1.1\%. Dow Jones Islamic Market Index Europe (DJIEU) sebesar 0,4\%. Dow Jones Islamic Market Index Japan (DJIJP) sebesar 0,1\%. Dow Jones Islamic Market Index Malaysia (DJIMY) sebesar 0,0\% dan guncangan Dow Jones Islamic Market Index China/ Hongkong (DJICHK) sebesar 0,1\%.

Pada periode ke-12 guncangan Jakarta Islamic Index (JII) yang disebabkan oleh variabel JII itu sendiri naik menjadi 98,84\%. Sedangkan variabel lain yang mempengaruhi guncangan Jakarta Islamic Index (JII) adalah Dow Jones Islamic Market Index United States (IMUS) sebesar 0,7\%. Dow Jones Islamic Market Index Europe (DJIEU) sebesar 0,3\%. Dow Jones Islamic Market Index Japan (DJIJP) 0,1\%. Dow Jones Islamic Market Index Malaysia (DJIMY) 0,1\% dan Guncangan Dow Jones Islamic Market Index China/ Hongkong (DJICHK) 0,1\%.

Pada akhir periode, yaitu pada periode ke-24 kontribusi dari Jakarta Islamic Index (JII) itu sendiri masih mendominasi bahkan meningkat sebesar 99,01\% dalam memberikan pengaruh guncangan terhadap Jakarta Islamic Index (JII). Sedangkan variabel lain dalam memberikan pengaruh guncangan terhadap Jakarta Islamic Index (JII) hanya dapat berkontribusi sebesar $0,1 \%$ oleh Dow Jones Islamic Market Index United States (IMUS), Dow Jones Islamic Market Index Europe (DJIEU) (0,3\%), Dow Jones Islamic Market Index Japan (DJIJP) (0,0\%), Dow Jones Islamic Market Index Malaysia (DJIMY) (O,1\%) dan Guncangan Dow Jones Islamic Market Index China/Hongkong (DJICHK) (0,0\%).

\section{SIMPULAN}

Berdasarkan penelitian yang telah dilakukan dapat disimpulkan bahwa semua variabel independen, yaitu: Dow Jones Islamic Market Index United States (IMUS), Dow Jones Islamic Market Index Europe (DJIEU), Dow Jones Islamic Market Index Japan (DJIJP), Dow Jones Islamic Market Index Malaysia (DJIMY), dan Dow Jones Islamic Market Index China/Hongkong (DJICHK) tidak memiliki pengaruh yang signifikan terhadap Jakarta Islamic Index (JII) pada jangka pendek. Sedangkan pada jangka panjang Dow Jones Islamic Market Index United States (IMUS) dan Dow Jones Islamic Market Index China/Hongkong (DJICHK) berpengaruh signifikan negatif terhadap Jakarta Islamic Index (JII). Adapun DJIJP dan DJIMY memiliki pengaruh signifikan positif terhadap Jakarta Islamic Index (JII) pada jangka panjang. Sementara Dow Jones Islamic Market Index Europe (DJIEU) tidak memiliki dampak yang signifikan terhadap Jakarta Islamic Index (JII) baik dalam jangka pendek maupun jangka panjang.

Hasil Uji IRF menunjukkan bahwa guncangan pada variabel Dow Jones Islamic Market Index United States (IMUS) direspon positif oleh Jakarta Islamic Index (JII) meski sempat 
mengalami respon negatif satu kali pada periode ketiga. Sedangkan variabel Dow Jones Islamic Market Index Europe (DJIEU) direspon positif oleh Jakarta Islamic Index (JII) dari awal hingga akhir periode. Guncangan pada variabel Dow Jones Islamic Market Index Malaysia (DJIMY) direspon positif oleh Jakarta Islamic Index (JII) meski sempat mendapat respon negatif pada periode keempat dan keenam. Adapun guncangan variabel Dow Jones Islamic Market Index Japan (DJIJP) dan Dow Jones Islamic Market Index China/Hongkong (DJICHK) direspon negatif pada awal periode oleh Jakarta Islamic Index (JII) kemudian mendapat respon positif pada periode ketiga dan kelima. Lalu kembali negatif pada periode keenam hingga akhir periode penelitian.

\section{REFERENSI}

Abduh, M., Omar, M. ., \& Duasa, J. (2011). The Impact Of Crisis And Macroeconomic Variables Towards Islamic Banking Deposits. American Journal of Applied, 8(1413-1418).

Abdullah, F., Hassan, T \& Mohamad, S. 2007. Investigation of performance of Malaysian Islamic unit trust funds: Comparison with conventional unit trust funds. Managerial Finance. 33 (2): 142-53.

Amsi, Mang. (2019). Ikhtisar Statistik Saham Syariah Indonesia 8 Juli 2019 https://www.syariahsaham.com/2019/07/ikhtisar-statistik-saham-syariah_8.html diakses pada 7 Januari 2020.

Beik, I. S. (2014). Pengaruh Indeks Harga Saham Syariah Internasional dan Variabel Makroekonomi Terhadap Jakarta Islamic Index. Al-Iqtishad.

Catherine S. F. Ho dkk, 2014. Performance of Global Islamic Versus Conventional Share Indices: International evidence. Journal Elsevier.

D N Nachrowi, U. H. 2006. Pendekatan Populer dan Praktis Ekonometrika Untuk Analisis Ekonomi dan Keuangan. Jakarta: Lembaga Penerbit Fakultas Ekonomi Universitas Indonesia

Farooq, M. O., \& Reza, H. M. (2014). Dow Jones Islamic Market US Index: Applying technical analysis from a comparative perspective. Journal Emeraldinsight.

Firdaus, M. (2011). Aplikasi Ekonometrika Untuk Data Panel dan Time Series. IPB Press.

Gujarati, D. 2003. Ekonometrika Dasar. Jakarta: Erlangga.

Hakim, S., \& Rashidian, M. (2002). Risk and Return of Islamic Stock Market Indexes. Economic Research Forum Annual Meetings Sharjah, UEA.

Huda, N., \& Nasution, M. (2008). Investasi pada Pasar Modal Syariah. Kencana Prenada Media Group.

Hussein, K., \& Omran, M. (2005). Ethical Investment Revisited. The Journal of Investing, 14(3), 
Prianto \& Darwanto. DJIMI \& JII

$105-126$.

Janitra, E. (2014). Do World Gold Price, Dow Jones Islamic Market and Inflation Affect the Performance of Jakarta Islamic Index? Jurnal Ekonomi Dan Pembangunan.

Jakarta Islamic Index. https://www.sahamonline.id/2017/05/jakarta-islamic-index-idx.html diakses pada 7 Januari 2020.

Juanda B \& Junaidi. 2012. Ekonometrika Deret Waktu Teori dan Aplikasi. Bogor: IPB Press.

Listiyaningsih, Erna. dan Chandrasekhar Krishnamurti. 2015. How Performance of Jakarta Islamic Index (JII) Stocks Relative to Other Stocks? Jurnal Dinamika Manajemen.

Mohamed Sherif, D. L. (2017). Shariah-Compliant Investment and Stock Returns: Evidence from the Indonesian Stock Market. Journal of Islamic Accounting and Business Research, 8(2).

Rodoni, A. (2009). Pasar Modal Syariah. Lembaga Penelitian UIN.

Rohman, A. Azhar. dan Mohd Herry Mohd Nasir. 2010. Islamic norms for Stock Screening: A comparison between the Kuala Lumpur Stock Exchange Islamic Index and the Dow Jones Islamic Market Index. Internastional Journal of Islamic and Middle Eastern Finance and Management.

S\&P Dow Jones Indices: Dow Jones Islamic Market Indices Methodology, July 2019.

Sims, C.A. 1972. Money, Income, and Causality. American Economic Review, Vol. 62, pp. 540552.

Soemitra. (2009). Bank dan Lembaga Kenangan Syariah. Kharisma Putra Utama.

Touiti, M., \& Henchiri, J. E. (2017). Risk and Performance of Islamic Indexes during Subprime Crisis. Second American Academic Research Conference on Global Business, Economics, Finance and Social Sciences. 